\title{
CAMBODIA'S SPECIAL ECONOMIC ZONES
}

Peter Warr and Jayant Menon

NO. 459

October 2015
ADB ECONOMICS WORKING PAPER SERIES 
ADB Economics Working Paper Series

\section{Cambodia's Special Economic Zones}

Peter Warr and Jayant Menon

No. 459 | October 2015
PeterWarr (Peter.Warr@anu.edu.au) is John Crawford Professor of Agricultural Economics, and Director, Poverty Research Centre at the Crawford School of Public Policy, Australian National University. Jayant Menon (jmenon@adb.org) is Lead Economist at the Economic Research and Regional Cooperation Department, Asian Development Bank.

The authors would like to acknowledge the kind cooperation of the Government of Cambodia, particularly the staff of the Council for the Development of Cambodia and the Ministry of Economy and Finance. Comments received from Sok Chenda Sophea, Eric Sidgwick, and participants at the Seventh GMS Economic Corridors Forum held in Kunming on 11 June 2015 were helpful in improving on an earlier draft. We are grateful to Tong Kimsun and colleagues at the Cambodia Development Resource Institute for their assistance in administering the firm-level survey. The paper has also benefited from the excellent research assistance of Anna Cassandra Melendez. 
Asian Development Bank

6 ADB Avenue, Mandaluyong City

1550 Metro Manila, Philippines

www.adb.org

(C) 2015 by Asian Development Bank

October 2015

ISSN 2313-6537 (Print), 2313-6545 (e-ISSN)

Publication Stock No. WPS157683-2

The views expressed in this paper are those of the authors and do not necessarily reflect the views and policies of the Asian Development Bank (ADB) or its Board of Governors or the governments they represent.

ADB does not guarantee the accuracy of the data included in this publication and accepts no responsibility for any consequence of their use.

By making any designation of or reference to a particular territory or geographic area, or by using the term "country" in this document, $A D B$ does not intend to make any judgments as to the legal or other status of any territory or area.

Note: In this publication, "\$” refers to US dollars.

The ADB Economics Working Paper Series is a forum for stimulating discussion and eliciting feedback on ongoing and recently completed research and policy studies undertaken by the Asian Development Bank (ADB) staff, consultants, or resource persons. The series deals with key economic and development problems, particularly those facing the Asia and Pacific region; as well as conceptual, analytical, or methodological issues relating to project/program economic analysis, and statistical data and measurement. The series aims to enhance the knowledge on Asia's development and policy challenges; strengthen analytical rigor and quality of ADB's country partnership strategies, and its subregional and country operations; and improve the quality and availability of statistical data and development indicators for monitoring development effectiveness.

The ADB Economics Working Paper Series is a quick-disseminating, informal publication whose titles could subsequently be revised for publication as articles in professional journals or chapters in books. The series is maintained by the Economic Research and Regional Cooperation Department. 


\section{CONTENTS}

TABLES

ABSTRACT V V

$\begin{array}{ll}\text { I. INTRODUCTION } & 1\end{array}$

II. SPECIAL ECONOMIC ZONES IN THE GLOBAL ECONOMY 1

III. LITERATURE ON SPECIAL ECONOMIC ZONES 3

IV. $\quad$ SPECIAL ECONOMIC ZONES IN CAMBODIA 6

V. COMPARISON OF FIRMS INSIDE AND OUTSIDE CAMBODIA'S SPECIAL ECONOMICZONES

VI. FIRM COMMENTS ON SPECIAL ECONOMIC ZONE EXPERIENCE 10

VII. SPECIAL ECONOMIC ZONE SURVEY FINDINGS

VIII. CONCLUSIONS

$\begin{array}{ll}\text { APPENDIX } & 15\end{array}$

$\begin{array}{ll}\text { REFERENCES } & 21\end{array}$ 


\section{TABLES}

\section{TABLES}

1. Static versus Dynamic Effects of Special Economic Zones 4

2 Special Economic Zones in Cambodia, 2014

3 Employment in Cambodia, $2013 \quad 7$

4 Special Economic Zone Survey Respondent Firms Summary 12 


\begin{abstract}
This study examines the role of special economic zones (SEZs) within the trade policy of Cambodia. It asks whether Cambodia's establishment of SEZs since late 2005 has been successful, based on the evidence to date, and analyzes the appropriate role and management of SEZs over the next decade or more. The study finds that the SEZs have attracted significant levels of foreign investment into Cambodia that would not have been present otherwise. These investments have created around 68,000 jobs, with equal or better pay and better prospects than the alternatives that would otherwise have existed, raising the economic welfare of the workers concerned. A feature of the Cambodian experience is that the government has left the establishment and management of the zones to private sector developers, avoiding the large and sometimes wasteful public sector set up costs associated with SEZ establishment in many other countries.
\end{abstract}

Keywords: Cambodia, foreign investment, production networks, special economic zones

JEL Classification: F21, F23, F63 


\section{INTRODUCTION}

This study examines the role of Special Economic Zones (SEZs) within the trade policy of Cambodia. It asks whether Cambodia's establishment of SEZs since late 2005 has been successful, based on the evidence to date, and analyzes the appropriate role and management of SEZs over the next decade or more. The report builds upon field work in Cambodia in October 2014, in which SEZs were visited in three locations within Cambodia, including one-on-one interviews with firms operating in various SEZs as well as managers and operators of the SEZs themselves, followed by a questionnaire-based survey of firms operating within Cambodia's SEZs conducted in October and November of 2014.

Special economic zones (SEZs) are legal, logistical, and tax arrangements intended to assist a developing country in attracting export-oriented manufacturing investment (mainly foreign) that would not otherwise happen. The domestic conditions that would otherwise discourage this investment include poor domestic infrastructure, security of investment, costly regulations and trade restrictions. The rationale of the SEZ is to reduce the costs associated with these deterrents, thereby attracting employment-creating investment into the country that would not have occurred without the SEZ. The zone creates a favorable investment environment within a limited geographic area, but does not directly address problems existing within the investment climate outside the zone. For that reason, they have often been called investment enclaves.

The study finds that the SEZs have attracted significant levels of foreign investment into Cambodia that would not have been present otherwise, creating around 68,000 jobs, with equal or better pay and better prospects than the alternatives that would otherwise have existed. A feature of the Cambodian experience is that the government has left the establishment and management of the zones to private sector developers, avoiding the large and sometimes wasteful public sector set up costs associated with SEZ establishment in many other countries. Section II discusses the changing role of SEZs within the global economy, including the rapidly growing importance of fragmented production systems. The economic literature on SEZs is reviewed in Section III with a focus on its relevance for developing countries like Cambodia. Section IV describes the development of SEZs in Cambodia, a relatively recent entrant to the global SEZ market. A recent World Bank study that compared firms inside and outside the SEZs is briefly described in Section V, along with its main findings. Section VI summarizes the results of the authors' interviews with SEZ firms in October 2014 focusing on the experience of these firms with the SEZ in which they are located. Section VII reviews the results of the study team's survey of SEZ firms conducted in October to November of 2014 and Section VIII concludes.

\section{SPECIAL ECONOMIC ZONES IN THE GLOBAL ECONOMY}

Since the 1960s, SEZs, also known as free trade zones or export processing zones, depending on the details of their regulations, have grown rapidly in Asia, Latin America, the Caribbean, and Africa. A universal feature of all such zones is duty-free importation of intermediate goods, provided the output produced is fully exported. According to the International Labor Office database on export processing zones (Boyenge 2007), in 1986 there were 176 of these zones in 47 countries. Two decades later, in 2006, there were 3,500 in 130 countries and total employment in these zones was 66 million, of which 40 million was in the People's Republic of China (PRC), 5.25 million in Mexico and Central America, and a further 3.25 million in bonded factories in Bangladesh. 
Production fragmentation is a global manufacturing development facilitated by the growth of SEZs. It has in turn accelerated demand for the services the zones offer. This phenomenon makes it possible for labor-intensive phases of the overall production process of a final good to be divided into many segments, which may differ widely in their cost structure. International trade in intermediate goods makes it possible for these individual processes to occur in different parts of the world, where cost conditions vary widely (Arndt and Kierzkowski 2001). The manufacturer's objective is to reduce the total cost of producing the final good. It pursues this goal by undertaking individual phases of the overall production process in the most suitable locations. Low-wage countries may have an advantage in attracting the most labor-intensive production processes, but not the most skill-intensive processes, because their work force lacks the necessary training. Specialized capital goods may be required for some such processes, but the increased international mobility of these capital goods greatly expands the scope for relocation of labor-intensive processes to low-wage countries (Jones 2000). Production fragmentation does not require SEZs, but these zones can provide a vehicle for attracting to developing countries the most labor-intensive phases of fragmented production processes.

The circumstances that induce multinational firms to locate particular phases of their overall production process in this or that country are multidimensional and can change quickly. For example, the PRC's positioning as a low-wage production base for labor-intensive production processes is changing rapidly due to increasing wages within the PRC, itself a consequence of the country's successful industrialization. Both Chinese and foreign firms are now looking to SEZs in less developed countries, among other possibilities, as vehicles for reducing total costs of producing their final products, by relocating the most labor-intensive processes to countries where labor costs are lower than in the PRC.

A further attraction of SEZs, from the viewpoint of investing firms, is to provide a reserve production base, where output can be increased quickly when operations in the firm's main base, in the PRC, Thailand or elsewhere, are disrupted for some reason. These reserve operations are often referred to as "the PRC-plus-one," "Thailand-plus-one," and so forth. For example, in October 2013 flooding in Thailand's Eastern provinces forced the temporary closure of at least 17 major enterprises in the Amata Nakorn Industrial Estate. Even more severe and more widespread flooding had occurred in 2011. The disruptions were costly, preventing many firms from meeting production deadlines, jeopardizing the production of final goods that depend crucially on each part of the supply chain. By having a reserve plant elsewhere, able to ramp up production at short notice, the costs of this sort of disruption can be reduced. For this to happen, the reserve plant requires very good connectivity to the international market to make possible rapid input delivery and export of finished products.

The benefits to the host country of establishing SEZs lie, overwhelmingly, in employment creation at attractive wages. Depending on the industry, workers who initially possess low skill levels may also receive training that is useful for subsequent employment. Tax revenue may be raised from the firms operating in the zones, depending on the tax regime that is offered, and demand may develop for inputs that can be produced within the domestic economy (backward linkages) rather than be imported. For some countries, most notably the PRC in the 1980s, SEZs have been viewed as policy experiments, within which policy reforms could be tried out for possible later adoption within the wider economy.

Five decades of global experience with SEZs has produced a number of lessons that new entrants to the field need to know about. 
First, SEZs tend to take as much as 5 to 10 years before producing the large-scale employment benefits that are hoped for (Farole 2011). This incubation period was experienced even in the most successful SEZs, in the PRC and Malaysia. Some patience is therefore needed.

Second, the SEZ will succeed in attracting new investors only if the zone offers significant cost advantages to internationally mobile manufacturers. It is important for planners to remember that these firms are not captives. They have alternatives and they will exercise them by exiting if the zone does not deliver the advantages they seek. After all, many of the firms that arrive in one SEZ have already exited another, after the expected advantages that brought them there had failed to materialize or had dissipated.

Third, although many countries have offered generous tax holidays to firms entering the zones, these holidays have made surprisingly little difference to the investment decisions of the firms (Farole 2011). Since tax holidays are costly in fiscal terms, they are of dubious merit. The literature of fiscal incentives is clear in its conclusion that they matter only at the margin, after factors such as political and macroeconomic stability are met (Farole 2011).

Fourth, SEZ firms often prefer to source their intermediate inputs internationally unless there is a clear cost advantage in doing otherwise. The reason is that the zone firms wish to retain their international mobility without disrupting their sources of inputs (Warr 1989). Hopes for large backward linkages and substantial levels of technology transfer to local suppliers are often disappointed. These linkages tend to develop only in countries like the PRC and Thailand where well-developed supporting industries, including local, small- and medium-sized enterprises, can be identified and provide cost advantages in sourcing inputs locally. The international evidence is that the existence of SEZs does not necessarily cause these local supporting industries to develop because the SEZ firms are not always interested in sourcing inputs locally. If the induced creation of local industries of this kind is viewed as a necessary condition for the success of the SEZ experiment, the international experience is not encouraging. Especially in poor countries, the principal benefits from establishing SEZs do not lie in this area.

Fifth, the domestic factors most important to firm decisions to invest in SEZ operations and subsequently to remain in them are labor costs; labor relations, especially freedom from strikes; reliability and cost of infrastructure, especially electricity; and the logistics of importing and exporting efficiently, without costly delays. Corruption at the border causes delay and cost increases, and SEZ firms are especially sensitive to these matters.

Finally, SEZs are most likely to produce benefits to the host country when they are part of a broad strategy of economic liberalization extending to the entire economy. When the SEZ is seen as an island of liberalization within an otherwise import substitution-based development strategy, the SEZ experiment may produce economic benefits, but they will be marginal.

\section{LITERATURE ON SPECIAL ECONOMIC ZONES}

The theoretical literature on the likely impacts of SEZs can be divided into two strands: (i) the orthodox approach, which draws on neoclassical economic theory; and (ii) the heterodox approach, which draws on endogenous growth theory and the new institutional economics. The orthodox approach focuses on the effects of SEZs on static economic welfare, resting on whether they contribute to or distort allocative efficiency. Hamada's 1974 study is considered the first study on SEZs 
to adopt this approach. It assesses SEZs primarily within the Hecksher-Olin model of international trade, focusing on static economic metrics and abstracting from possible secondary, catalytic effects. The static effects include direct employment generation, foreign direct investment inflows, foreign exchange earnings, and economic value-added. This approach views SEZs as a second best option to full trade liberalization; as such, SEZs are best treated as a transitory policy instrument which loses its significance as the country adopts full-fledged market reforms (Warr 1989, Aggarwal 2010, Baissac 2011, Farole and Akinci 2011, Cheesman 2012, and Woolfrey 2013).

The heterodox approach, on the other hand, emphasizes dynamic effects and sees SEZs playing a more catalytic role in promoting broader economic growth. This approach has dominated much of the work on SEZs since the late 1980s. Building on endogenous growth and new institutional theories, the heterodox approach views SEZs as having dynamic spillover effects, extending benefits beyond their enclaves through their impact on backward linkages, human capital, technology, and institutional reforms (Milberg and Amengual 2008, Aggarwal 2010, and Baissac 2011). Table 1 below summarizes the static versus dynamic benefits expected from SEZs, according to this literature.

Table 1: Static versus Dynamic Effects of Special Economic Zones

\begin{tabular}{ll}
\hline Static Benefits & Dynamic Benefits \\
\hline Foreign exchange earnings & Skills upgrading \\
Foreign direct investment & Testing field for wider economic reform \\
Employment generation & Technology transfer \\
Government revenue & Demonstration effect \\
Export growth & Export diversification \\
& Enhancing trade efficiency of domestic firms \\
& Formation of industry clusters \\
& Integration into global value chains \\
\hline
\end{tabular}

Source: Adapted from Zeng (2011a), extended to include Aggarwal (2010).

Recent literature on SEZs further emphasizes the dynamic and indirect effects that they might have. This literature has been influenced heavily by the "new economic geography" (NEG), which stresses skill formation, knowledge spillover, technology spillovers, and backward and forward linkages (Cheesman 2012). This literature also emphasizes cluster effects, in which similar firms group together with positive spillovers of the kind hypothesized by the NEG. Aggarwal (2010) extends the earlier heterodox approach to include their potential impact on industrial formation of industry clusters and the integration of domestic firms into global value chains. Aggarwal (2010), FIAS (2008) and Baissac (2011) consider agglomeration and global value chains as important drivers of competitiveness and industrial upgrading, and view SEZs as making important contributions to both outcomes.

It should be emphasized that the NEG literature is largely theoretical, with high- and uppermiddle-income countries the main examples offered for the arguments being made. Its relevance for the actual circumstances of SEZs in least developed countries is unclear and the present study will return to this set of issues in light of the experience of Cambodia, discussed below.

Studies on the impact of SEZs have produced mixed results. FIAS (2008) reports that SEZs can be an effective tool for job creation, particularly in economies with small populations. Farole and Akinci (2011) also cite empirical research which shows that many SEZs have been successful in generating exports and employment and that SEZs have commonly come out marginally positive in 
most cost-benefit assessments. Milberg and Amengual (2008) note that most research from the 1990s finds scant evidence of SEZs' positive impact on backward linkages, technology transfer, or industrial upgrading. They stress that while some economies, such as the Republic of Korea and Taipei,China in Asia, have managed to create substantial linkages (see also Farole and Akinci 2011), domestic orders remain at a very low level, with the most common range of domestically purchased inputs lying between $3 \%$ and $9 \%$. The authors also note that technological spillovers are rare, since the low-skill assembly type production commonly found in SEZs are not conducive to technology transfer. Finally, while developing economies have managed to increase their share of world exports of manufactured goods, their share of manufacturing value-added has not increased proportionally, suggesting that SEZs have failed to spur industrial upgrading significantly.

As for SEZs catalyzing the formation of industry clusters, Zeng (2011a) cites Krugman and Venables (1996) to argue that industry clusters are formed mainly by market forces or by accident. While some clusters have risen out of SEZs, Zeng notes that these have been slower to develop, and that it is "easier to devise policies for a functioning cluster and devilishly hard to call a cluster into existence, especially when the essential industrial nuclei are difficult to identify" (Zeng 2011b, p. 7; citing Yusuf, Nabeshima, and Yamashita 2008).

Despite the substantial body of work on the theoretical underpinnings of SEZs and their contribution to development outcomes, critical knowledge gaps remain. First, most studies examining the impact of SEZs have employed descriptive analyses and case studies of selected SEZs. But very little has been done in the area of formal, empirical analysis. Second, in the case of Asia, the existing research has tended to focus on the newly industrialized economies such as the Republic of Korea and Taipei,China, or the original members of the Association of Southeast Asian Nations. Very little work has been done on the experiences of Asian least developed economies.

A serious limitation of the literature on SEZs is that it tends to search for both characteristics of SEZs and the benefits the host country may expect from them that are similar for all host countries. It largely overlooks the fact that host countries vary greatly in their level of development, from primarily agrarian African economies, to middle-income industrializing economies in Asia, and finally to advanced industrial economies in Europe, North America, and some Asian countries. The SEZ is an administrative and legal platform that will result in forms of investment and levels of interaction with the domestic economy that depend on the stage of development of the host country. This helps explain why the characterization of the impact of SEZs varies so much. Rather than describing mutually inconsistent representations of the same phenomenon, the various strands of the SEZ literature are better understood as stylized descriptions of SEZs at different stages of host country development.

Stage I. In low-income countries, enclave development must be expected from SEZs because the domestic economy is insufficiently developed to sustain backward linkages from the SEZ firms to domestic firms. The host economy is characterized by low productivity agricultural employment and the main benefit derived from the SEZ is to employ large numbers of people in higher productivity and higher paid unskilled and semiskilled manufacturing jobs. This stage of host country development corresponds to the "orthodox" SEZ literature discussed above and examples include the SEZs located in Sub-Saharan Africa, South Asia, and less developed countries of Southeast Asia (Warr 1989).

Stage II. In more advanced economies, linkages between footloose SEZ firms and domestic firms become profitable because they reduce SEZ firms' costs. Dynamic effects within the host country result from the technology transfer that results from these backward linkages. This stage of 
host country development corresponds to the "heterodox" SEZ literature discussed above. Examples include the SEZs of Northeast Asia and Malaysia (Athukorala 2014).

Stage III. At higher levels of host country development, SEZs can facilitate the formation of clusters of industrial enterprises that produce mutually beneficial interactions among themselves. This is what the NEG literature is describing. Examples include the SEZs in Ireland and North America.

\section{SPECIAL ECONOMIC ZONES IN CAMBODIA}

The legal framework for SEZs in Cambodia was established by a government subdecree issued in late 2005. In 2014, there were nine such zones operating in the country, listed in Table 2, with a further 20 authorized to begin operations. The SEZs are still relatively small. Total employment in all of Cambodia's SEZs is currently around 68,000. Manhattan SEZ in Bavet is the largest single SEZ, with total employment of 28,000, while the other two SEZs in Bavet employ a further 8,000. Phnom Penh SEZ employs 17,000 workers, Shanoukville's three SEZs employ just under 10,000 and the zones in the Thai border areas of Koh Kong and Poi Pet employ just under 5,000. The SEZs therefore represent just under $1 \%$ of total employment and $3.7 \%$ of total secondary industry employment in Cambodia (Table 3). By comparison, Cambodia's garments sector, mostly outside the SEZS reportedly accounts for about 600,000 employees, about $38 \%$ of total secondary industry employment, or 10 times the size of all SEZs combined.

Table 2: Special Economic Zones in Cambodia, 2014

\begin{tabular}{llcccc}
\hline Location & \multicolumn{1}{c}{ Name of SEZ } & $\begin{array}{c}\text { Year } \\
\text { Established }\end{array}$ & $\begin{array}{c}\text { Number } \\
\text { of Firms } \\
\text { Operating }\end{array}$ & $\begin{array}{c}\text { Total } \\
\text { Employment }\end{array}$ & $\begin{array}{c}\text { Employees } \\
\text { per Firm } \\
\text { (avg) }\end{array}$ \\
\hline Phnom Penh & Phnom Penh SEZ & 2008 & 50 & 17,000 & 340 \\
Bavet & Manhattan SEZ & 2006 & 26 & 28,051 & 1,079 \\
& Tai Seng Bavet SEZ & 2007 & 17 & 7,968 & 469 \\
& Dragon King SEZ & 2013 & 2 & 280 & 140 \\
\multirow{2}{*}{ Sihanoukville } & Sihanoukville SEZ1 & 2009 & 2 & 424 & 212 \\
& Sihanoukville SEZ 2 & 2008 & 40 & 8,967 & 224 \\
& Sihanoukville Port SEZ & 2012 & 2 & 416 & 208 \\
Poi Pet & Poi Pet O'Neang SEZ & 2011 & 2 & 830 & 415 \\
Koh Kong & Neang Kok Koh Kong SEZ & 2005 & 4 & 3,953 & 988 \\
Total & All Cambodian SEZs & 2005 & 145 & 67,889 & 468 \\
\hline
\end{tabular}

SEZ = special economic zone.

Source: Council for the Development of Cambodia, Government of Cambodia. http://www.cambodiainvestment.gov.kh/list-of-sez.html

The government's purpose in establishing SEZs was to promote diversification of the industrial base beyond electronics, to establish economic linkages between urban and rural areas and to promote industrial investment outside Phnom Penh (World Bank 2012). Cambodia's SEZs are almost entirely 
privately owned and managed. ${ }^{1}$ To establish an SEZ an operator needs at least 50 hectares (124 acres) of land and must establish the roads, electricity, and water supply to service prospective firms. The firms choosing to locate in the zone are then contractually required to purchase electricity from the zone operator, a source of friction between zone proprietors and firms when cheaper sources of power become available from sources outside the SEZ.

Table 3: Employment in Cambodia, 2013

\begin{tabular}{lrrrr}
\hline Industrial Sector (main occupation) & Cambodia & Phnom Penh & Other Urban & Other Rural \\
\hline Employed population, (thousands) & 7,951 & 942 & 810 & 6,199 \\
Agriculture (Primary) & 3,871 & 19 & 108 & 3,743 \\
Industry (Secondary) & 1,579 & 236 & 152 & 1,191 \\
Services (Tertiary) & 2,501 & 687 & 550 & 1,265 \\
& & & & \\
Sectoral share of total employment (\%) & & & & \\
Agriculture (Primary) & 48.7 & 2.0 & 13.4 & 60.4 \\
Industry (Secondary) & 19.9 & 25.1 & 18.8 & 19.2 \\
Services (Tertiary) & 31.5 & 72.9 & 67.9 & 20.4 \\
Total & 100.0 & 100.0 & 100.0 & 100.0 \\
\hline
\end{tabular}

Source: Cambodia Social Economic Survey 2013. http://www.nis.gov.kh/index.php/en/find-statistic/social-statistics/cses/cses-tables.html (accessed 16 October 2014).

The government provides a "one-stop" service in which representatives of all relevant government ministries are present on the SEZ site, available to process on the site the documentation firms require for export, import, employment, and other regulatory matters. This service is intended to remove the necessity for firms to visit ministry offices in Phnom Penh for all but the most important matters. The cost of providing this one-stop administrative service must be met by the zone operator, who charges the firms locating within the zone a fee for the package of services provided.

A firm wishing to locate in an SEZ must first obtain government approval as a Qualified Investment Project (QIP), which requires that the firm have a minimum of $\$ 500,000$ fixed assets. There is no distinction between foreign and domestic firms in this respect, but almost all of the firms located in the SEZs are foreign. Approval as a QIP entitles the firm to receive certain government incentives, and it is possible for a QIP firm to locate either inside or outside the SEZs, receiving the QIP incentives whether the firm is inside an SEZ or not.

Outside the SEZs, Cambodia's manufacturing sector is heavily dominated by garment firms. This is less true inside the SEZs, where the industrial base is more diversified, including a higher proportion of firms producing electronics, electrical products, and household furnishings than are found outside the zones. Industrial diversification was one of the government's objectives in establishing SEZs and this objective has been met, to a degree. It has the advantage that if the global garment industry suffers a downturn, employment in Cambodia's manufacturing sector will be less vulnerable to this downturn to the extent that it is diversified.

Of the SEZ firms visited by the research team, none purchase any intermediate inputs from the domestic economy, importing all of these inputs, and almost none produce for the domestic market,

1 A partial exception is the small Sihanoukville Port SEZ, which is a public-private joint venture financed by the Japanese Industrial Cooperation Agency loan. 
exporting virtually all outputs. ${ }^{2}$ Linkages with the domestic Cambodian economy are therefore limited to employment, most of which are low-skilled production operators, purchase of electricity and water, rental of Cambodian land for the factory sites, and payment of taxes, if any.

Labor costs are low in Cambodia and this is why firms were initially attracted to the SEZs, together with, in some cases, favorable tariff treatment in the European Union and the United States for goods produced in Cambodia. Although employment conditions in the SEZs seem relatively good, by Cambodian standards, wages paid seldom exceed the legal minimum, not counting prescribed transport and lunch allowances. The legal minimum in Cambodia is currently $\$ 100$ per month, plus legally mandated lunch and transport allowances, making a total of about $\$ 145$ per month, plus payment for any overtime, leading to average total wages of between $\$ 160$ and $\$ 180$ per month. Wages in Cambodia's garments sector, a good guide to those paid in the SEZs, are summarized in the figure below. Real wages have risen in recent years and it is possible, though not at all certain, that the era of cheap labor in Cambodia may be approaching its end, implying rising wages. Of course, this is a welcome sign of progress, but it means that Cambodia's edge in attracting investment in laborintensive manufacturing may abate if productivity does not rise.

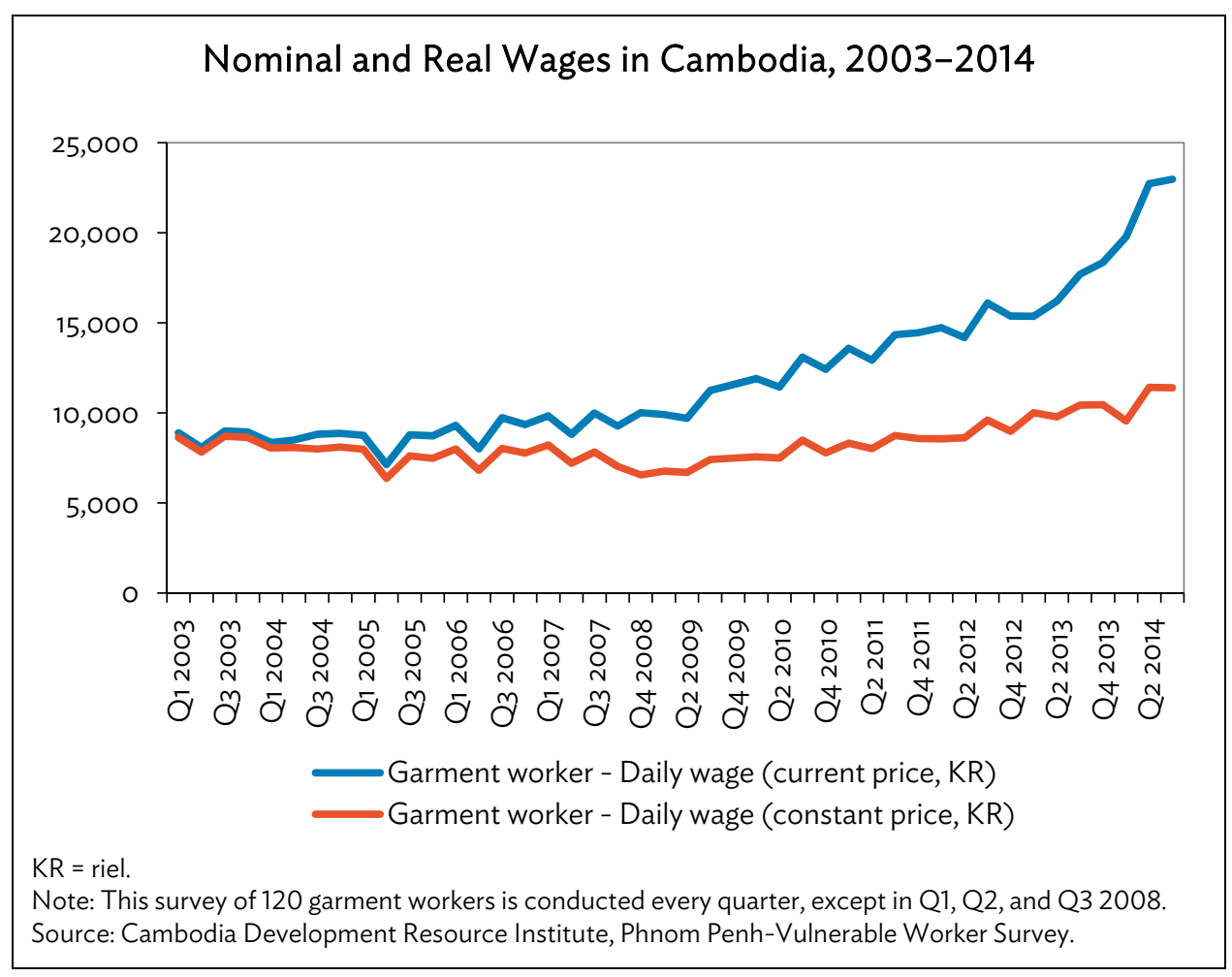

At least $95 \%$ of production workers employed in the SEZs are women. It is said that females possess the nimble fingers and patience with routine tasks required by the labor-intensive processes generally occurring in the zones and that they are also less likely than males to strike or disrupt production in other ways. The ages of production workers are generally 18 to 30 and their home bases

2 The exception is one Japanese firm which produces packaging material exclusively for a Cambodian beer manufacturer, Angkor. A few other firms indicated that a small share of output is sometimes sold domestically, especially when export demand is slack. In such cases, the firm is legally obliged to pay import duty on the imported intermediate goods used in the production process. 
are increasingly the most outlying provinces of Cambodia, rather than Phnom Penh. Recruitment of new workers from Phnom Penh is said to have become very difficult.

The economic literature on Cambodia's SEZs is thin. Abonyi, Zola, and Suwannakarn (2013) use a case study approach to examine the role of SEZs in developing border economic areas and linkages between Thailand and other countries in the Greater Mekong Subregion. Bafoil et al. (2011) also use case studies from the PRC, Cambodia, and the Lao People's Democratic Republic to draw lessons and identify weaknesses in the Laotian and Cambodian context, compared to the PRC's experience. Cambodia's Diagnostic Trade Integration Strategy and Trade SWAp Roadmap for 20142018 (Ministry of Commerce 2014) also has a chapter on SEZs, analyzing their strengths, weaknesses, opportunities, and threats. Finally, World Bank (2012) surveyed SEZ and non-SEZ firms in an attempt to isolate the impact of operating within an SEZ. The findings are discussed in the following section.

\section{COMPARISON OF FIRMS INSIDE AND OUTSIDE CAMBODIA'S SPECIAL ECONOMIC ZONES}

An Enterprise Survey for Cambodia, conducted by the World Bank in 2012, surveyed industrial firms in the country, including 32 SEZ firms and 830 non-SEZ firms. By restricting the sample of non-SEZ firms to those of similar size and operating in similar industries to SEZ firms, it was possible to assess the differences arising from location in the SEZ itself. The main findings from this comparison include the following average characteristics.

(i) SEZ firms tend to be younger (SEZ 2.3, non-SEZ 13.2 years) and larger (SEZ 616, nonSEZ 430 employees).

(ii) SEZ firms are more export-oriented (SEZ 70.3\%, non-SEZ 25.5\% of total sales).

(iii) SEZ firms are more likely to be foreign-controlled (SEZ 93.8\%, non-SEZ 38.4\% foreign ownership).

(iv) No significant difference in labor productivity or total factor productivity could be found between SEZ and non-SEZ firms, although value-added per unit of output is slightly higher in the SEZs.

(v) SEZ firms are more likely to use technology licensed from a foreign-owned firm (SEZ $40 \%$, non-SEZ 14\%) and are more likely to have an internationally recognized quality certification (SEZ 25\%, non-SEZ 8\%), but they are less likely to invest in product and process innovation or in formal research and development activities. That is, SEZ firms purchase their technology under license but do not invest in research and development themselves.

(vi) SEZ firms source a very limited proportion of their inputs from the domestic economy (SEZ 12\%, non-SEZ 62\%).

(vii) SEZ firms sell a smaller proportion of their output domestically (SEZ 27\%, non-SEZ $63 \%)$.

(viii) Average monthly wages were slightly lower in SEZ firms (SEZ \$100, non-SEZ \$105), though this difference could reflect differences in rates of overtime.

(ix) SEZ firms invest more in training their workers (SEZ 36\% and 79\% of production and non-production workers trained, respectively; non-SEZ 9\% and 36\%, respectively).

( $x$ ) SEZ and non-SEZ firms report a similar set of factors as being "major" or "very severe" constraints to their operations: corruption (SEZ 74.2\%, non-SEZ 38.1\%), skills and education of available workers (SEZ 71.9\%, non-SEZ 36.7\%), macroeconomic instability (SEZ 43.8\%, non-SEZ 40.4\%), electricity (SEZ 40.6\%, non-SEZ 39.8\%), and regulatory 
policy uncertainty (SEZ 34.4\%, non-SEZ 14.5\%). The higher rates of dissatisfaction among SEZ firms seemingly indicate that the expectations held at the time the firms entered the SEZs have not been fully met. Non-SEZ firms apparently did not share the same high expectations.

The above observations do not suggest that the NEG literature reviewed above is particularly relevant for SEZs in Cambodia. The firms occupying the SEZs are, if anything, less promising candidates for technology transfer than non-SEZ firms because their technology tends either to be low level or purchased on license from elsewhere. Firms in Cambodia's SEZs invest less in research and development than non-SEZ firms. Skills formation could be a source of benefit for the local economy, but again it is not apparent that the SEZ firms offer more benefit in this respect than those outside the zones. Backward and forward linkages are very small because SEZ firms import most of their inputs and export most of their output. Both backward and forward linkages are more significant outside the SEZs than within. This partly reflects the difference in the sectoral composition of the firms, as well as the fact that most firms outside the SEZs are engaged in the nontraded goods sector. Cambodia's SEZs are classic enclaves, linked to the international economy but not to the domestic economy. The NEG may or may not be relevant for SEZs in more advanced economies, but its emphasis is misplaced when applied to Cambodia, and presumably countries like it and its policy implications are potentially misleading.

\section{FIRM COMMENTS ON SPECIAL ECONOMIC ZONE EXPERIENCE}

The research team visited 11 SEZ firms-Phnom Penh (3 firms), Bavet (4 firms), and Sihanoukville (4 firms) -in addition to SEZ administrators in each of these locations. The comments of these firms on their experience in the SEZ included the following major points.

(i) Several firms commented that their expectations on entering the SEZ had not been fully met. At least in some locations, the "one-stop" administrative service is not a single stop. In the extreme, the outcome can be summarized as "one-extra-stop," as described by one manager. The general experience seems to be that the "one-stop" facility does reduce regulatory compliance costs, but not enough to satisfy firm managers.

(ii) It was commented that Cambodian workers can reach satisfactory levels of productivity but require higher levels of training and longer periods of adjustment to achieve these levels than workers in neighboring Thailand and Viet Nam. The average standard of literacy is not high and 30\% of new employees have apparently never attended school and cannot read. These workers can be employed only in the most routine manual operations.

(iii) Some comments indicated that recruitment is becoming more difficult for zone firms. Rates of worker turnover are high and firms report that they must make special efforts to recruit new workers in the most outlying provinces of Cambodia. The labor market appears to be geographically segmented, with limited rural-urban migration at present. Recruitment from Phnom Penh or other major cities is reportedly very difficult. On the other hand, firms do not appear to be offering wages above the legal minimum (plus legally required bonuses) to attract workers, so the situation cannot (yet) be described as one of labor shortage.

(iv) It was reported that additional payments and "gifts" are demanded by government officials in most interactions. That is, the administration of the SEZs is not corruptionfree. One firm manager commented that being in the SEZ makes it easier for government 
officials to target them for special payments when it is known that large outward or inward shipments are about to occur.

(v) Electricity costs are a frequent source of complaint. In the Phnom Penh SEZ, electricity costs $\$ 0.20$ per kilowatt-hour, compared with $\$ 0.07$ in Thailand and Viet Nam. Electricity accounts for an average of around one-fourth of variable costs, depending on the industry. Interruptions to electricity supplies are frequent, depending on the site, requiring firms to install expensive backup generators using diesel power, costing around $\$ 0.28$ per kilowatt-hour. In some locations water quality and waste disposal are also problems.

(vi) The SEZ is a fenced area with restricted access from outside. This provides a security benefit which means that workers are safe within the zone area, and also that firms can be shielded from striking demonstrators, who can sometimes be a security threat for firms located outside the SEZs. Once the workers leave the SEZ area, safety can be a problem.

(vii) Multiple shifts are not as common as they might be. One suggestion for encouraging multiple shifts would be to offer off-peak electricity tariffs below daytime peak rates. This would provide an incentive for firms to operate a second shift outside normal working hours, thereby increasing total employment and making more efficient use of the factory's fixed investments.

\section{SPECIAL ECONOMIC ZONE SURVEY FINDINGS}

SEZ firms were surveyed with a questionnaire, administered with the assistance of staff of the Cambodia Development Resource Institute and the kind cooperation of the Council for the Development of Cambodia and the SEZ administrators in the SEZs listed in Table 4. For logistical reasons, the four SEZ firms located in the Koh Kong SEZ in Southwestern Cambodia (Table 2 above) could not be included in the survey. All 141 firms were asked to complete the questionnaire, with assurance that individual firm responses would be confidential, and 58 firms did so, a response rate of $41 \%$. Although response rates were not uniform across the SEZ locations surveyed, based on the average numbers of employees per firm (471 among respondents compared with 468 for all SEZ firms) it does seem likely that the results are representative. Appendix Tables A.1 to A.11 summarize the findings from these 58 respondent firms.

Firms in SEZs are unenthusiastic about the quality of public services available to them and the infrastructure provided. An issue of particular concern is electricity. This dissatisfaction is greatest in Bavet and Poipet, where electricity supplies are frequently disrupted, even though the unit cost of electricity is relatively low. Reflecting this, garments sector firms were the most critical of electricity provision. The reliability of electricity supplies seems to be a greater concern than the cost. Most SEZ firms rent the land on which they operate, except for those in the Phnom Penh SEZ, where more than half the firms own their land.

Almost all production workers are Cambodian (Khmer), both low-skilled and semiskilled, and two-thirds of all nonproduction workers are also Cambodian. The important exception to the latter is in Sihanoukville, where more than half of nonproduction workers are foreign, predominantly Chinese, reflecting the Chinese ownership of most firms located there. Average wages of production workers are higher in Bavet and Sihanoukville than in Phnom Penh, but the reverse applies to nonproduction workers. Salaries of nonproduction workers are on average roughly four times those of low-skilled production workers, though this ratio is higher in Phnom Penh than elsewhere. The main labor problem 
identified by SEZ firms is the low level of skill possessed by their new recruits. Most SEZ firms provide in-house training for their local employees but less than a quarter of these use local training institutions as part of this activity. Foreign sources of capital dominate the financing of SEZ firms, with the firms' own resources the most important, followed by investment from other foreign sources. Local sources of finance are negligible.

Table 4: Special Economic Zone Survey Respondent Firms Summary

\begin{tabular}{lcccccc} 
& & \multicolumn{5}{c}{ Respondent Firms Summary } \\
\cline { 2 - 6 } & $\begin{array}{l}\text { Respondent } \\
\text { Firms }\end{array}$ & $\begin{array}{c}\text { Percentage } \\
\text { of Sales } \\
\text { That are } \\
\text { Lirect } \\
\text { Exports }\end{array}$ & $\begin{array}{c}\text { Part of } \\
\text { Global } \\
\text { Supply } \\
\text { Chain } \\
(\%)\end{array}$ & $\begin{array}{c}\text { Percentage } \\
\text { of Inputs } \\
\text { That are } \\
\text { Imported }\end{array}$ & $\begin{array}{c}\text { Employees } \\
\text { per Firm } \\
\text { (avg) }\end{array}$ & $\begin{array}{c}\text { Shifts } \\
\text { per Day } \\
\text { (avg) }\end{array}$ \\
\hline $\begin{array}{l}\text { Phnom Penh } \\
\text { Bavet }\end{array}$ & 11 & 100 & 73 & 92 & 274 & 1.2 \\
Sihanoukville & 18 & 97 & 89 & 86 & 1,035 & 1.3 \\
Poipet & 28 & 100 & 86 & 85 & 191 & 1.2 \\
Footwear & 1 & 100 & 100 & 100 & 330 & 1.0 \\
Garments & 7 & 100 & 57 & 56 & 1,076 & 1.4 \\
Home furnishings & 14 & 96 & 100 & 95 & 608 & 1.3 \\
Light machinery & 14 & 100 & 93 & 89 & 296 & 1.2 \\
Luggage and bags & 7 & 100 & 71 & 83 & 251 & 1.0 \\
Other light mfg. & 5 & 100 & 100 & 90 & 159 & 1.0 \\
All respondent firms & 11 & 100 & 82 & 92 & 417 & 1.2 \\
\hline
\end{tabular}

Note: The four firms in Koh Kong noted in Table 2 were not surveyed.

Source: Survey of SEZ firms, October-November 2014.

Essentially all of respondent firms' sales are international, exported directly by the SEZ firm itself. Imported inputs account for an average of $87 \%$ of all inputs. The main exceptions are found in the footwear industry, where almost half of the intermediate inputs used are local. Aside from these special cases, the SEZ firms are integrated with global markets but not well integrated with the Cambodian economy. Their main logistics concern is the cost of getting containers from their factory to and from the port.

Most firms report the existence of an SEZ administration team and about three-fourths of firms confirm regular meetings with the zone administrators, averaging six meetings per year. Nearly all firms reported satisfaction with this aspect of zone functioning. Fiscal incentives appear to be most important in the case of exports and unimportant in all other cases. 


\section{CONCLUSIONS}

Within the international literature on SEZs two criteria for the "success and sustainability" of SEZs are frequently cited: (i) that they address key constraints faced by investors to improve their competitive performance relative to the rest of the economy; and (ii) that enterprises in SEZs establish effective linkages with the rest of the economy to improve its overall competitiveness, through supplier relations, transfers of technology, knowledge, and spurring policy reform. ${ }^{3}$ It is not always clear whether these two criteria for success are based on empirical evidence or on a priori theorizing, but the implication is that if SEZs do not meet these two criteria, they have failed. It is argued here that these criteria are of limited relevance for a developing country like Cambodia. Although Cambodia's SEZs have so far not satisfied either criterion, they are not failing.

Regarding the first point, to attract the footloose labor-intensive phase of fragmented production processes, the important point is not whether the SEZ marginally improves the investment climate within the zone compared with that prevailing in the rest of the same country, outside the zone. Rather, it is whether the environment within the zone is competitive compared with alternative international sites available to firms looking to reduce the cost of labor-intensive phases of their overall production process. If all the SEZ does is to encourage firms already operating within the country to relocate to the zone, it would seem likely that nothing significant has been achieved. It is in attracting new investments into the country, thereby generating new employment, which would not exist in the absence of the SEZ, that a genuine contribution can be made.

Regarding the second point, Cambodia's experience to date indicates clearly that SEZ firms are not closely linked to the domestic Cambodian economy, and significantly less so than similar firms operating outside the zones, in terms of both forward and backward linkages. But, contrary to the implications of the recent literature, this does not mean that the zones are failing. They contribute to the economic welfare of the Cambodian people and have the potential to increase this contribution. Even if value-added per unit of output is small and is confined to the labor-intensive enclave activities occurring in the zones themselves, this can be important if the total volume of output is large. The potential for labor-intensive manufacturing employment to expand is vast, given the huge volume of internationally footloose production that exists in the region. By providing employment at higher wages than unskilled workers can obtain in alternative employment, which may be agricultural work in Cambodia or in neighboring Thailand, the incomes of the people involved can be increased substantially. It need hardly be said that this is not in itself the answer to Cambodia's long-term development problems. It is at best a component, possibly temporary, of a package of policy measures designed to raise incomes, but it is valuable for the people concerned.

Even though SEZ firms are so far not closely linked to domestic firms within Cambodia, SEZs may have a significant demonstration effect. By showing that manufacturing investment can be successful, beyond the trade preference-driven labor-intensive garments sector that currently dominates manufacturing in Cambodia, the development of SEZs may indirectly promote foreign direct investment outside the zones, though that effect will of course take time.

An interesting feature of the Cambodian SEZ policy is that government has left the establishment and management of the zones to private sector developers. This has avoided the large and sometimes wasteful public sector set up costs associated with SEZ establishment in many other

3 Farole (2011) is often cited in this connection. 
countries. It also introduces greater market disciplines into the running and management of the SEZs, adding to their long-term viability.

The role of SEZs as experimental sites for policy reform was apparently important in the PRC during the late 1980s and early 1990s. It could be important in countries like Cambodia as well, although this argument assumes that governments are more able to learn from events occurring within their own borders than from events observable in similar countries elsewhere. The domestic policy measures needed to enhance the international competitiveness of the zones are similar to those needed in the rest of the economy (US Department of State 2013). Infrastructure must be upgraded, to reduce transport costs. Trade facilitation must be improved to reduce costs and delays associated with importing and exporting. Electricity supplies must be improved, especially as regards the reliability of electricity supply. Corruption must be reduced and rules of payment to government agencies clarified. Most important, but most difficult, labor quality must be improved by investment in basic literacy and numeracy. The experience of SEZs can help focus attention on these critical policy issues. 


\section{APPENDIX: SEZ SURVEY RESULTS SUMMARY}

\section{Table A.1: Firm Assessment of Overall Business Environment}

\begin{tabular}{lccc}
\hline Location & $\begin{array}{c}\text { Quality of } \\
\text { Infrastructure }\end{array}$ & $\begin{array}{c}\text { Quality of } \\
\text { Public Services }\end{array}$ & $\begin{array}{c}\text { Variability of Government } \\
\text { Policies }\end{array}$ \\
\hline Phnom Penh & 2.6 & 2.7 & 2.3 \\
Bavet & 2.9 & 3.1 & 2.1 \\
Sihanoukville & 2.3 & 2.6 & 1.9 \\
Poipet & 3.0 & 3.0 & 2.0 \\
& & & \\
Footwear & 2.4 & 2.6 & 1.7 \\
Garments & 2.6 & 2.9 & 1.9 \\
Home furnishings & 2.3 & 2.8 & 2.2 \\
Light machinery & 2.9 & 2.7 & 1.9 \\
Luggage and bags & 2.4 & 2.2 & 1.4 \\
Other light manufacturing & 2.8 & 3.0 & 2.5 \\
& & & \\
All respondent firms & 2.6 & 2.8 & 2.0 \\
\hline
\end{tabular}

Notes: Columns 1 and 2: 1 = Very good, $2=$ Good, $3=$ Average, $4=$ Poor, $5=$ Very poor. Column 3: $1=$ Very high, $2=$ High, $3=$ Average, 4 = Low, 5 = Very low.

Source: Survey of SEZ firms, October- November 2014.

Table A.2: Firm Assessment of Basic Infrastructure

\begin{tabular}{lcccc}
\hline Location & Water & Waste Disposal & Telecommunications & Electricity \\
\hline Phnom Penh & 1.4 & 2.1 & 2.3 & 1.8 \\
Bavet & 1.9 & 2.0 & 2.1 & 2.7 \\
Sihanoukville & 1.8 & 1.9 & 2.2 & 2.3 \\
Poipet & 2.0 & 2.0 & 3.0 & 3.0 \\
& & & & \\
Footwear & 1.7 & 1.9 & 1.6 & 2.1 \\
Garments & 1.9 & 1.9 & 2.1 & 2.6 \\
Home furnishings & 1.6 & 1.9 & 2.6 & 2.2 \\
Light machinery & 1.9 & 2.3 & 2.3 & 2.4 \\
Luggage and bags & 2.0 & 1.6 & 2.0 & 2.4 \\
Other light manufacturing & 1.7 & 2.2 & 2.3 & \\
& & & & 2.4 \\
All respondent firms & 1.8 & 2.0 & 2.2 & \\
\hline
\end{tabular}

Notes: 1 = Good, 2 = Average, 3 = Poor.

Source: Survey of SEZ firms, October-November 2014. 


\section{Table A.3: Land Use}

\begin{tabular}{lccc}
\hline Location & $\begin{array}{c}\text { Land Use per Firm } \\
\text { (square meters) }\end{array}$ & Percentage Rented & Rental per Month \\
\hline Phnom Penh & 18,110 & 44 & 5,181 \\
Bavet & 42,512 & 72 & 33,243 \\
Sihanoukville & 9,194 & 75 & 10,248 \\
Poipet & 13,285 & 100 & 316 \\
& & & \\
Footwear & 17,686 & 71 & 10,118 \\
Garments & 29,150 & 64 & 23,543 \\
Home furnishings & 20,328 & 50 & 10,411 \\
Light machinery & 8,348 & 86 & 7,205 \\
Luggage and bags & 3,741 & 100 & 7,660 \\
Other light manufacturing & 31,048 & 91 & 25,660 \\
& & & 15,515 \\
\hline
\end{tabular}

Source: Survey of SEZ firms, October-November 2014.

Table A.4: Employment Numbers

(total)

\begin{tabular}{|c|c|c|c|c|c|c|}
\hline \multirow[t]{2}{*}{ Location } & \multicolumn{2}{|c|}{$\begin{array}{c}\text { Low-Skilled Production } \\
\text { Workers }\end{array}$} & \multicolumn{2}{|c|}{$\begin{array}{c}\text { Semiskilled Production } \\
\text { Workers }\end{array}$} & \multicolumn{2}{|c|}{$\begin{array}{c}\text { Nonproduction } \\
\text { Workers (managers, } \\
\text { administration, sales) }\end{array}$} \\
\hline & Khmer & Foreign & Khmer & Foreign & Khmer & Foreign \\
\hline Phnom Penh & 2,294 & 0 & 491 & 42 & 129 & 42 \\
\hline Bavet & 9,542 & 19 & 7,621 & 109 & 567 & 213 \\
\hline Sihanoukville & 2,142 & 7 & 2,262 & 17 & 94 & 118 \\
\hline Poipet & 315 & 0 & 15 & 0 & 2 & 0 \\
\hline Footwear & 6,068 & 0 & 1,097 & 12 & 233 & 51 \\
\hline Garments & 3,881 & 0 & 4,367 & 85 & 179 & 73 \\
\hline Home furnishings & 1,190 & 0 & 2,039 & 11 & 118 & 137 \\
\hline Light machinery & 256 & 0 & 1,326 & 5 & 112 & 60 \\
\hline Luggage and bags & 150 & 7 & 622 & 1 & 16 & 16 \\
\hline Other light manufacturing & 2,748 & 19 & 938 & 54 & 134 & 36 \\
\hline All respondent firms & 14,293 & 26 & 10,389 & 168 & 792 & 373 \\
\hline
\end{tabular}

Source: Survey of SEZ firms, October-November 2014. 
Table A.5: Employment Numbers

(average per firm)

\begin{tabular}{|c|c|c|c|c|c|c|}
\hline \multirow[t]{2}{*}{ Location } & \multicolumn{2}{|c|}{$\begin{array}{c}\text { Low-Skilled Production } \\
\text { Workers }\end{array}$} & \multicolumn{2}{|c|}{$\begin{array}{c}\text { Semiskilled Production } \\
\text { Workers }\end{array}$} & \multicolumn{2}{|c|}{$\begin{array}{c}\text { Nonproduction } \\
\text { Workers (managers, } \\
\text { administration, sales) }\end{array}$} \\
\hline & Khmer & Foreign & Khmer & Foreign & Khmer & Foreign \\
\hline Phnom Penh & 229 & 0 & 55 & 14 & 13 & 5 \\
\hline Bavet & 636 & 19 & 448 & 16 & 33 & 13 \\
\hline Sihanoukville & 93 & 7 & 103 & 2 & 4 & 5 \\
\hline Poipet & 315 & 0 & 15 & 0 & 2 & 0 \\
\hline Footwear & 1,011 & 0 & 219 & 12 & 39 & 9 \\
\hline Garments & 323 & 0 & 364 & 17 & 13 & 5 \\
\hline Home furnishings & 99 & 0 & 170 & 3 & 9 & 11 \\
\hline Light machinery & 51 & 0 & 189 & 3 & 22 & 10 \\
\hline Luggage and bags & 30 & 7 & 124 & 1 & 3 & 3 \\
\hline Other light manufacturing & 305 & 19 & 117 & 14 & 13 & 4 \\
\hline All respondent firms & 292 & 13 & 212 & 10 & 15 & 7 \\
\hline
\end{tabular}

Source: Survey of SEZ firms, October-November 2014

Table A.6: Average Wages

(\$ per month)

\begin{tabular}{lccc}
\hline Location & $\begin{array}{c}\text { Low-Skilled Production } \\
\text { Workers }\end{array}$ & $\begin{array}{c}\text { Semiskilled Production } \\
\text { Workers }\end{array}$ & $\begin{array}{c}\text { Nonproduction Workers } \\
\text { (managers, foreman) }\end{array}$ \\
\hline Phnom Penh & 119 & 366 & 686 \\
Bavet & 135 & 175 & 379 \\
Sihanoukville & 131 & 235 & 549 \\
Poipet & 110 & 130 & 330 \\
& & & \\
Footwear & 135 & 202 & 520 \\
Garments & 130 & 184 & 304 \\
Home furnishings & 122 & 304 & 782 \\
Light machinery & 145 & 273 & 583 \\
Luggage and bags & 143 & 161 & 478 \\
Other light manufacturing & 124 & 287 & 450 \\
& & & \\
All respondent firms & 129 & 243 & 522 \\
\hline
\end{tabular}

Source: Survey of SEZ firms, October-November 2014. 


\section{Table A.7: Training Programs and Labor Problems}

(\% answering yes)

\begin{tabular}{|c|c|c|c|c|c|}
\hline \multirow[b]{2}{*}{ Location } & \multirow{2}{*}{$\begin{array}{l}\text { Formal Training } \\
\text { for Local } \\
\text { Employees }\end{array}$} & \multirow{2}{*}{$\begin{array}{l}\text { Linkages with } \\
\text { Local Training } \\
\text { Institutions }\end{array}$} & \multicolumn{3}{|c|}{ Major Labor Problems } \\
\hline & & & High Cost & Low Skills & High Turnove \\
\hline Phnom Penh & 73 & 19 & 27 & 46 & 18 \\
\hline Bavet & 78 & 28 & 17 & 50 & 11 \\
\hline Sihanoukville & 86 & 11 & 14 & 43 & 32 \\
\hline Poipet & 100 & 100 & 0 & 0 & 100 \\
\hline Footwear & 100 & 29 & 29 & 43 & 14 \\
\hline Garments & 71 & 29 & 7 & 57 & 21 \\
\hline Home furnishings & 86 & 7 & 14 & 50 & 21 \\
\hline Light machinery & 57 & 0 & 14 & 57 & 14 \\
\hline Luggage and bags & 100 & 20 & 40 & 40 & 20 \\
\hline Other light manufacturing & 82 & 18 & 18 & 18 & 45 \\
\hline All respondent firms & 81 & 17 & 17 & 45 & 24 \\
\hline
\end{tabular}

Note: Major labor problems may not add to 100 when other labor problems were also mentioned.

Source: Survey of SEZ firms, October-November 2014.

Table A.8: Sources of Capital

(\%)

\begin{tabular}{lcccc}
\hline Location & Own Source & Bank Loans & Supplier Credit & $\begin{array}{c}\text { Foreign Direct } \\
\text { Investment }\end{array}$ \\
\hline Phnom Penh & 45 & 0 & 0 & 45 \\
Bavet & 44 & 6 & 6 & 39 \\
Sihanoukville & 93 & 0 & 0 & 4 \\
Poipet & 100 & 0 & 0 & 0 \\
& & & 14 & 14 \\
Footwear & 43 & 0 & 0 & 36 \\
Garments & 57 & 7 & 0 & 14 \\
Home furnishings & 86 & 0 & 0 & 29 \\
Light machinery & 71 & 0 & 0 & 0 \\
Luggage and bags & 100 & 0 & 0 & 27 \\
Other light manufacturing & 64 & 0 & & 22 \\
All respondent firms & 69 & 2 & 2 & \\
\hline
\end{tabular}

Note: Sources of credit may not add to 100 when multiple sources were used or when other sources were also mentioned.

Source: Survey of SEZ firms, October-November 2014. 
Table A.9: Transport Cost and Logistics Problems

\begin{tabular}{lcccc}
\hline & $\begin{array}{c}\text { Average } \\
\text { Transport Cost } \\
\text { per Container to }\end{array}$ & \multicolumn{3}{c}{ Major Logistics Difficulty } \\
\cline { 3 - 5 } Location & Port $(\$)$ & High Cost & $\begin{array}{c}\text { Uncertainty in } \\
\text { Delivery Dates }\end{array}$ & $\begin{array}{c}\text { Lack of Multimodal } \\
\text { Connectivity }\end{array}$ \\
\hline Phnom Penh & 1,500 & 100 & 0 & 0 \\
Bavet & 503 & 78 & 11 & 0 \\
Sihanoukville & 500 & 46 & 11 & 11 \\
Poipet & 250 & 100 & 0 & 0 \\
Footwear & 489 & 57 & & 0 \\
Garments & 599 & 64 & 7 & 0 \\
Home furnishings & 743 & 71 & 7 & 0 \\
Light machinery & 738 & 71 & 14 & 0 \\
Luggage and bags & 338 & 80 & 0 & 0 \\
Other light manufacturing & 544 & 55 & 18 & 5 \\
All respondent firms & & 66 & 9 & \\
\hline
\end{tabular}

Note: Major logistics difficulties may not add to 100 when other problems were also mentioned.

Source: Survey of SEZ firms, October-November 2014.

Table A.10: Zone Management

\begin{tabular}{|c|c|c|c|c|c|c|}
\hline \multirow[b]{2}{*}{ Location } & \multirow{2}{*}{$\begin{array}{l}\text { Does an SEZ } \\
\text { administration } \\
\text { team exist? } \\
\text { (\% saying yes) }\end{array}$} & \multicolumn{3}{|c|}{ If yes, how well does it function? } & \multirow[t]{2}{*}{$\begin{array}{l}\text { Are there } \\
\text { regular } \\
\text { meetings } \\
\text { with the } \\
\text { SEZ? }\end{array}$} & \multirow{2}{*}{$\begin{array}{c}\text { If yes, } \\
\text { number of } \\
\text { meetings pe } \\
\text { year }\end{array}$} \\
\hline & & Good & Average & Poor & & \\
\hline Phnom Penh & 73 & 50 & 50 & 0 & 100 & 5 \\
\hline Bavet & 94 & 47 & 47 & 6 & 71 & 7 \\
\hline Sihanoukville & 100 & 43 & 54 & 4 & 68 & 5 \\
\hline Poipet & 0 & - & - & - & 0 & - \\
\hline Footwear & 100 & 14 & 86 & 0 & 86 & 6 \\
\hline Garments & 100 & 29 & 57 & 14 & 50 & 7 \\
\hline Home furnishings & 86 & 71 & 14 & 0 & 86 & 6 \\
\hline Light machinery & 86 & 29 & 57 & 0 & 29 & 6 \\
\hline Luggage and bags & 100 & 40 & 40 & 20 & 60 & 6 \\
\hline Other light manufacturing & 82 & 45 & 55 & 0 & 82 & 6 \\
\hline All respondent firms & 91 & 45 & 51 & 4 & 74 & 6 \\
\hline
\end{tabular}

SEZ = special economic zone.

Source: Survey of SEZ firms, October-November 2014. 
$20 \mid$ Appendix

Table A.11: Special Fiscal Incentives

(\% saying yes)

\begin{tabular}{lcccccc}
\hline & $\begin{array}{c}\text { Land } \\
\text { Rental }\end{array}$ & Employment & Capital & $\begin{array}{c}\text { Use of } \\
\text { Exports }\end{array}$ & $\begin{array}{c}\text { Specific } \\
\text { Technology }\end{array}$ & $\begin{array}{c}\text { Environmental } \\
\text { Issues }\end{array}$ \\
\hline Phnom Penh & 18 & 45 & 27 & 45 & 27 & 18 \\
Bavet & 11 & 11 & 6 & 22 & 0 & 17 \\
Sihanoukville & 4 & 14 & 11 & 21 & 11 & 18 \\
Poipet & 0 & 0 & 0 & 0 & 0 & 0 \\
Footwear & 0 & 29 & 0 & 29 & 14 & 43 \\
Garments & 7 & 7 & 7 & 14 & 0 & 29 \\
Home furnishings & 0 & 21 & 14 & 43 & 21 & 7 \\
Light machinery & 0 & 29 & 0 & 29 & 0 & 0 \\
Luggage and bags & 0 & 20 & 0 & 0 & 0 & 0 \\
Other light manufacturing & 36 & 18 & 36 & 27 & 18 & 18 \\
All respondent firms & 9 & 19 & 12 & 26 & 10 & 17 \\
\hline
\end{tabular}

Source: Survey of SEZ firms, October-November 2014. 


\section{REFERENCES*}

Abonyi, G., A. M. Zola, and E. Suwannakarn. 2013. Support for Implementing the Action Plan for Transport and Trade Facilitation in the GMS: Scoping Study on Developing Border Economic Areas and Cross-border Linkages between Thailand and its Neighbors. Prepared for the Asian Development Bank, Thailand Resident Mission.

Aggarwal, A. 2010. Economic Impacts of SEZs: Theoretical Approaches and Analysis of Newly Notified SEZs in India. Munich Personal RePec Archive Paper No. 20902. https://mpra.ub.unimuenchen.de/20902/

Arndt, S. and H. Kierzkowski, eds. 2001. Fragmentation: New Production Patterns in the World Economy. Oxford: Oxford University Press.

Athukorala, P.-C. 2014. Growing with Global Production Sharing: The Tale of Penang Export Hub, Malaysia. Competition and Change. 18 (3). pp. 221-45.

Bafoil F., N. Diaz, S. Guerin, A. Morris, and S. Sen. 2011. Depending Growth, SEZ in the Greater Mekong Subregion. MPA, Sciences Po. http://www.sciencespo.fr/coesionet/sites/default/files/GMS\% 20Capstone\%20Report\%20May\%2017.pdf

Baissac, C. 2011. Brief History of SEZs and Overview of Policy Debates. In T. Farole, ed. Special Economic Zones in Africa: Comparing Performance and Learning from Global Experiences. Washington, DC: The World Bank. http://elibrary.worldbank.org/doi/pdf/10.1596/978-0-8213 $-8638-5$

Boyenge, J. 2007. ILO database on export processing zones (Revised). ILO Working Paper No. 251. Geneva: International Labour Organization. http://staging.ilo.org/public/libdoc/ilo/2007/ 107B09_80_engl.pdf

Cheesman, A. 2012. Special Economic Zones \& Development: Geography and Linkages in the Indian EOU Scheme. DPU Working Paper No. 145. London: The Bartlett/University College London. http://www.bartlett.ucl.ac.uk/dpu/publications/dpu/latest/publications/dpu-working -papers/WP145.pdf

Council for the Development of Cambodia, Government of Cambodia. http://www .cambodiainvestment.gov.kh/list-of-sez.html

Farole, T., ed. 2011. Special Economic Zones in Africa: Comparing Performance and Learning from Global Experiences. Washington, DC: The World Bank. http://elibrary.worldbank.org/doi/pdf/ 10.1596/978-0-8213-8638-5

Farole, T. and G. Akinci, eds. 2011. Special Economic Zones Progress, Emerging Challenges, and Future Directions. Washington, DC: The World Bank. https://openknowledge.worldbank.org/ bitstream/handle/10986/2341/638440PUB0Exto00Box0361527BOPUBLIC0.pdf? sequence=1

\footnotetext{
* ADB recognizes “China” as the People's Republic of China.
} 
FIAS. 2008. Special Economic Zones: Performance, Lessons Learned, and Implications for Zone Development. The Multi-Donor Investment Climate Advisory Service of the World Bank Group. Washington, DC: The World Bank. https:/www.wbginvestmentclimate.org/uploads/ SEZs\%20-\%20Performance,\%20Lessons\%20Learned\%20and\%20Implications\%20for \%20Zone\%20Development.pdf

Hamada, K. 1974. An Economic Analysis of the Duty-Free Zone. Journal of International Economics. 4 (3). pp. 225-41.

Jones, R. W. 2000. Globalization and the Theory of Input Trade. Cambridge, MA: MIT Press.

Krugman, P. and A. Venables. 1996. Integration, Specialization, and Adjustment. European Economic Review. 40 (3-5). pp. 959-67.

Milberg, W. and M. Amengual. 2008. Economic Development and Working Conditions in Export Processing Zones: A Survey of Trends. WP.3. Geneva: ILO. http://ilo.org/public/french/ dialogue/download/wp3englishfinal.pdf

Ministry of Commerce, Kingdom of Cambodia. 2014. Cambodia's Diagnostic Trade Integration Strategy and Trade SWAp Roadmap 2014-2018. Phnom Penh.

US Department of State. 2013. 2013 Investment Climate Statement-Cambodia. http://www.state.gov/ e/eb/rls/othr/ics/2013/204614.htm

Warr, P. 1989. Export Processing Zones: The Economics of Enclave Manufacturing. The World Bank Research Observer. 4 (1). pp. 65-88.

Woolfrey, S. 2013. Special Economic Zones and Regional Integration in Africa. Stellenboch: Tralac. http://www.tralac.org/files/2013/07/S13WP102013-Woolfrey-Special-economic-zonesregional-integration-in-Africa-20130710-fin.pdf

World Bank. 2012. Cambodia Enterprise Survey 2012. Washington, DC.

Yusuf, S., K. Nabeshima, and S. Yamashita, eds. 2008. Growing Industrial Clusters in Asia: Serendipity and Science. Washington, DC: The World Bank.

Zeng, D. 2011. How Do Special Economic Zones and Industrial Clusters Drive China's Rapid Development? In D. Zeng, ed. Building Engines for Growth and Competitiveness in China. Experience with Special Economic Zones and Industrial Clusters. Washington, DC: The World Bank. https://openknowledge.worldbank.org/bitstream/handle/10986/2501/564470PUB Obuil10Box349496B01PUBLIC1.pdf? sequence=1

Zeng, D., ed. 2011. Building Engines for Growth and Competitiveness in China. Experience with Special Economic Zones and Industrial Clusters. Washington, DC: The World Bank. https://openknowledge.worldbank.org/bitstream/handle/10986/2501/564470PUBObuil10Box34 9496B01PUBLIC1.pdf? sequence $=1$ 


\section{Cambodia's Special Economic Zones}

This study examines the role of Special Economic Zones (SEZs) in Cambodia, and finds that the SEZs have attracted significant levels of foreign investment that would not have been present otherwise. These investments have created around 68,000 jobs, with equal or better pay and better prospects than the alternatives. By leaving it to the private sector, Cambodia has avoided the large and sometimes wasteful public sector set-up costs associated with SEZ establishment in many other countries.

\section{About the Asian Development Bank}

ADB's vision is an Asia and Pacific region free of poverty. Its mission is to help its developing member countries reduce poverty and improve the quality of life of their people. Despite the region's many successes, it remains home to the majority of the world's poor. ADB is committed to reducing poverty through inclusive economic growth, environmentally sustainable growth, and regional integration.

Based in Manila, ADB is owned by 67 members, including 48 from the region. Its main instruments for helping its developing member countries are policy dialogue, loans, equity investments, guarantees, grants, and technical assistance. 